\title{
PENGARUH KONSELING DENGAN MEDIA LEMBAR BALIK DAN BROSUR TERHADAP PENGETAHUAN TENTANG GAYA HIDUP PADA PASIEN DM TIPE 2 DI POLI RAWAT JALAN RSUD DELI SERDANG
}

\author{
Rosmawati Helmi Barus ${ }^{1}$, Donal Nababan², Frida Lina Tarigan ${ }^{3}$ \\ ${ }^{1}$ Program Studi Magister Kesehatan Masyarakat, Universitas Mutiara Indonesia Medan \\ Email :rosma3170@gmail.com \\ ${ }^{2}$ Direktorat Pasca Sarjana Ilmu Kesehatan Masyarakat, Universitas Mutiara Indonesia Medan \\ Email :nababan_donal@yahoo.com \\ ${ }^{3}$ Direktorat Pasca Sarjana Ilmu Kesehatan Masyarakat, Universitas Sari Mutiara Indonesia Medan \\ Email : frida_tarigan@yahoo.co.id
}

Masuk: 05-09-2019, revisi: 08-11-2019, diterima untuk diterbitkan: 18-11-2019

\begin{abstract}
ABSTRAK
Diabetes Melitus (DM) merupakan salah satu penyakit berbahaya yang dikenal oleh masyarakat Indonesia dengan nama penyakit kencing manis. DM adalah penyakit gangguan metabolik yang terjadi secara kronis atau menahun karena tubuh tidak mempunyai hormon insulin yang cukup akibat gangguan pada sekresi insulin, hormon insulin yang tidak bekerja sebagaimana mestinya atau keduanya. Tujuan penelitian ini adalah untuk mengetahui pengaruh konseling dengan media lembar balik dan brosur terhadap pengetahuan tentang gaya hidup pada pasien DM Tipe 2 di Poliklinik Rawat Jalan RSUD Deli Serdang Tahun 2019. Penelitian ini menggunakan quasi eksperimental design dengan menggunakan rancangan two group posttest. Populasi adalah seluruh pasien dengan penyakit DM Tipe 2 yang terdapat di Poli Rawat Jalan RSUD Deli Serdang sebanyak 199 dan sampel diperoleh 48 responden dengan ketentuan 24 untuk kelompok media lembar balik dan 24 untuk kelompok media brosur. Data dianalisis menggunakan analisis univariat dan bivariat. Hasil penelitian diperoleh: a) Ada pengaruh konseling dengan media lembar balik $(p=0,000)$ dan media brosur $(p=0,000)$ terhadap pengetahuan tentang gaya hidup pada pasien penderita DM Tipe 2. b) Media brosur lebih efektif berpengaruh terhadap pengetahuan tentang gaya hidup pada pasien penderita DM Tipe $2(\mathrm{p}=0,002)$. Dari hasil penelitian diharapkan penderita DM tipe 2 dapat menjaga gaya hidup yang sehat dengan melakukan diet yang benar untuk menjaga kebugaran tubuh dan mengontrol kadar gula darah dalam tubuh sehingga penyakitnya tidak menjadi komplikasi serta pihak rumah sakit dapat melakukan konseling kepada penderita DM tipe 2 menggunakan media brosur dan media lembar balik sebagai perwujudan kepedulian kepada pasien dan masyarakat.
\end{abstract}

Kata Kunci: Media Brosur; Media Lembar Balik; Pengetahuan; DM Tipe 2

\begin{abstract}
Diabetes mellitus (DM) is a dangerous disease known by the people of Indonesia by the name of diabetes. DM is a metabolic disorder that occurs chronic or chronic because the body does not have enough insulin due to interference with the secretion of insulin, insulin hormone that does not work properly or both. The purpose of this study was to determine the effect of counseling with flipcharts and brochures on lifestyle knowledge in Type 2 DM patients in the Outpatient Clinic of Deli Serdang Hospital in 2019. This study used a quasi experimental design using the two group posttest design. The population was all patients with Type 2 DM in the Outpatient Hospital Deli Serdang as much as 199 and the sample was obtained by 48 respondents with the provisions of 24 for the flip sheet media group and 24 for the brochure media group. Data were analyzed using univariate and bivariate analysis. The results were obtained: a) There was an influence of counseling with flipchart media $(p=0,000)$ and media brochures $(p=0,000)$ on lifestyle knowledge in patients with Type 2 diabetes. B) Media brochures more effectively influenced knowledge about lifestyle in patients with Type 2 diabetes $(p=0.002)$. From the results of the study it is expected that sufferers of type 2 DM can maintain a healthy lifestyle by doing the right diet to maintain body fitness and control blood sugar levels in the body so that the disease is not a complication and the hospital can counsel with patients with type 2 DM using media brochures and flipchart media as a manifestation of concern for patients and the community.
\end{abstract}

Keywords: Brochure Media; Flip Sheet Media; Knowledge; Type 2 diabetes 


\section{PENDAHULUAN \\ Latar Belakang}

Definisi kesehatan menurut Undang-Undang Republik Indonesia nomor 36 tahun 2009 adalah keadaan sehat, baik fisik, mental, spiritual maupun sosial yang memungkinkan setiap orang untuk hidup produktif secara sosial dan ekonomis. Kesehatan sebagai hak asasi manusia harus diwujudkan dalam bentuk pemberian berbagai pelayanan kesehatan kepada seluruh masyarakat melalui penyelenggaraan pembangunan kesehatan yang menyeluruh oleh Pemerintah, Pemerintah Daerah dan masyarakat secara terarah, terpadu dan berkesinambungan, adil dan merata, serta aman, berkualitas dan terjangkau oleh masyarakat. Oleh karena itu perlu dilakukan upaya kesehatan yang bertujuan untuk meningkatkan kualitas hidup manusia secara terpadu dan berkesinambungan. Upaya pelayanan kesehatan dapat berupa pemeliharaan kesehatan (promotif), pencegahan penyakit (preventif), penyembuhan penyakit (kuratif) dan pemulihan kesehatan (rehabilitatif) (Depkes, 2009).

Salah satu aspek pelayanan kesehatan yang paling penting adalah pelayanan yang diberikan oleh rumah sakit. Dimana rumah sakit menurut WHO (World Health Organization) adalah bagian integral dari suatu organisasi dan kesehatan dengan fungsi pelayanan paripurna (komprehensif), penyembuhan penyakit (kuratif) dan pencegahan penyakit (preventif) kepada masyarakat. Rumah sakit memiliki banyak multi disiplin ilmu seperti dokter, perawat, bidan, tenaga ahli kesehatan lain dan tenaga non kesehatan.

Promosi kesehatan yang ada di rumah sakit dibawahi oleh Tim PKRS (Promosi Kesehatan Rumah Sakit). Tim tersebut bergerak dalam upaya promotif, memberikan informasi kepada pasien terkait kesehatan. Sehingga, dimaksudkan untuk meningkatkan kepedulian terhadap kesehatan yang akan berdampak pada meningkatnya derajat kesehatan masyarakat. Tim PKRS bergerak menggunakan banyak medis, seperti Leaflet, Brosur, Spanduk dan lain-lain. Hal tersebut bertujuan untuk memudahkan pasien untuk memahami informasi yang diberikan (Kemenkes, 2018).

Perkembangan yang terjadi di dunia dengan semakin meningkatnya kemakmuran, kemajuan teknologi dan pertumbuhan ekonomi yang sangat cepat memiliki pengaruh terhadap kejadian dan jenis penyakit yang ada di masyarakat. Telah terjadi pergeseran jensi penyakit, dimana penyakit infeksi dahulu sangat mendominasi, akan tetapi saat ini penyakit yang berkaitan dengan proses degenerative dan gaya hidup semakin meningkat, walau sebenarnya kejadian penyakit infeksi juga masih cukup tinggi. Hal ini berkaitan dengan faktor genetik, lingkungan, pergeseran gaya hidup yang tidak sehat serta kurangnya aktivitas fisik (Tuncay, et all, 2008).

Saat ini banyak penyakit yang menyerang masyarakat, dimana ada penyakit menular dan penyakit tidak menular. Penyakit tidak menular adalah penyakit yang salah satunya disebabkan oleh gaya hidup atau keturunan. Contoh penyakit tidak menular yang paling banyak diderita oleh masyarakat yaitu Diabetes Mellitus (DM). Dimana Diabetes mellitus (DM) yang umum dikenal sebagai kencing manis adalah penyakit yang ditandai dengan hiperglikemia (peningkatan kadar gula darah) yang terus menerus dan bervariasi, terutama setelah makan. Diabetes mellitus merupakan penyakit gangguan metabolik menahun akibat pankreas tidak memproduksi cukup insulin atau tubuh tidak dapat menggunakan insulin yang diproduksi secara efektif . Insulin adalah hormon yang mengatur keseimbangan kadar gula darah. Akibatnya terjadi peningkatan konsentrasi glukosa di dalam darah (Kemenkes RI, 2014). 
Jumlah penderita diabetes mellitus secara global terus meningkat setiap tahunnya. Menurut data yang dipublikasikan oleh World Health Organization (WHO) angka kejadian diabetes mellitus di dunia berkembang dari 30 juta pada tahun 1985 menjadi 194 juta pada tahun 2006. Pada tahun 2025 diperkirakan angka ini terus meningkat mencapai 333 juta. Penderita diabetes mellitus di Indonesia jumlahnya cukup fantastis, pada tahun 2006 ditemukan 14 juta diabetes mellitus, WHO memperkirakan pada 2030 nanti sekitar 21,3 juta orang Indonesia akan terkena penyakit diabetes mellitus (Depkes RI, 2000). Pada tahun 2013, salah satu beban pengeluaran kesehatan terbesar di dunia adalah diabetes yaitu sekitar 612 miliar dolar, diestimasikan sekitar $11 \%$ dari total pembelanjaan untuk langsung kesehatan dunia. Pada tahun 2012, diabetes merupakan penyebab kematian kedelapan pada kedua jenis kelamin dan penyebab kematian kelima pada perempuan.

Menurut data yang dipublikasikan oleh WHO, diabetes merupakan salah satu dari empat prioritas penyakit tidak menular. Penyebab utama kebutaan, serangan jantung, stroke, gagal ginjal dan amputasi kaki. 80\% kejadian diabetes dapat dicegah, oleh karena itu dibutukan pemahaman yang baik kepada seluruh masyarakat. Diabetes juga dapat dikontrol sehingga penderita dapat berumur panjang dan hidup sehat. Pada tahun 2015, terdapat 1 dari 11 orang dewasa menderita diabetes (WHO, 2016).

Berdasarkan data WHO pula, pada tahun 2015 di Indonesia menempati peringkat ke tujuh dunia untuk prevalensi penderita diabetes tertinggi di dunia bersama China, India, Amerika Serikat, Brazil, Rusia dan Meksiko dengan jumlah estimasi orang dengan diabetes sebesar 10 juta. Diabetes juga merupakan penyebab kematian tertinggi ke tiga di Indonesia. Prevalensi orang dengan diabetes di Indonesia menunjukkan kecenderungan meningkat yaitu dari 5,7\% (2007) menjadi 6,9\% (2013) (WHO, 2015).

Berdasarkan Pusat Data dan Informasi Kementerian Kesehatan RI (2014), Sumatera Utara menempi posisi keenam setelah Sulawesi Utara, Sulawesi Selatan, Sulawesi Tengah, DKI Jakarta, NTT dan DI Yogyakarta. Dimana angka orang yang pernah didiagnosa menderita kencing manis oleh dokter sebesar 2,3\% atu sejumlah 160.913 jiwa (dengan usia <15 tahun). Besar jumlah penderita tersebut juga sejalan dengan RSUD. Deli Serdang, dimana RSUD. Deli Serdang adalah satu-satunya rumah sakit umum milik Pemerintah Kabupaten Deli Serdang, merupakan pusat rujukan pelayanan dengan status kelas B pendidikan. Disana terdapat juga jumlah pasien DM yang semakin meningkat, yaitu 2.275 kasus. Yang terdiri dari 237 kasus pada Bulan Januari, 310 pada Bulan Februari, 397 pada Bulan April, 190 pada Bulan Mei, 198 pada Bulan Juni, 136 pada Bulan Juli, 178 pada Bulan Agustus,192 Pada Bulan September, 172 pada Bulan Oktober, 186 pada Bulan November dan 241 pada Bulan Desember pada Tahun 2018.

Berdasarkan survei awal yang dilakukan di RSUD. Deli Serdang, memang banyak ditemui pasien-pasien dengan penyakit DM. Peneliti melakukan wawancara singkat kepada beberapa pasien dan didapati bahwa rendahnya pengetahuan terkait diabetes mellitus yang dimiliki oleh pasien, gaya hidup pasien yang kurang baik terdiri dari pola makan tidak sehat, obesitas dan kurangnya aktivitas fisik. Pasien tersebut belum pernah mendapatkan konseling maupun edukasi dengan brosur dan lembar balik. Oleh karena itu, peneliti tertarik untuk melakukan penelitian terkait "Pengaruh Konseling Dengan Media Lembar Balik Dan Brosur Terhadap Pengetahuan Pada Pasien DM Tipe 2 Di Poliklinik Rawat Jalan RSUD Deli Serdang Tahun 2019”. 


\section{METODE PENELITIAN}

Penelitian ini menggunakan quasi eksperimental design dengan menggunakan rancangan two group posttest. Observasi dilakukan dua kali yaitu sebelum eksperimen dan sesudah eksperimen, penelitian dilakukan di Poli Rawat Jalan RSUD Deli Serdang, populasinya adalah seluruh pasien dengan penyakit DM Tipe 2 yang terdapat di Poli Rawat Jalan RSUD Deli Serdang sebanyak 199 penderita DM tipe 2, Sampel pada penelitian ini adalah pasien DM Tipe 2 yang mendapatkan konseling di Poliklinik Dokter Spesialis RSUD Deli Serdang, sebanyak 48 orang Dengan teknik penarikan sampel adalah purposive sampling, dengan pemilihan sampel yang memenuhi kriteria penelitian pada saat konseling akan dilakukan, dan dari sampel tersebut akan di bagi menjadi dua kelompok eksperimen, 24 responden kelompok lembar balik dan 24 responden kelompok brosur.

\section{HASIL DAN PEMBAHASAN}

Hasil analisis dalam penelitian ini dibuat dalam bentuk analisis Univariat dan analysis Bivariat.

\section{Analisa Univariat}

Tabel .1 Hasil Distribusi Frekuensi Pengetahuan Tentang Gaya Hidup Pada Pasien Di Poliklinik Rawat Jalan RSUD Deli Serdang Tahun 2019 Pada Kelompok Media Lembar Balik

\begin{tabular}{lllll}
\hline \multirow{3}{*}{ Variabel Pengetahuan } & \multicolumn{4}{l}{ Media Lembar Balik } \\
\cline { 2 - 5 } & \multicolumn{2}{l}{ Pre-Test } & \multicolumn{3}{l}{ Post Test } \\
\cline { 2 - 5 } & $\mathbf{f}$ & $\mathbf{\%}$ & $\mathbf{f}$ & \% \\
\hline Baik & 14 & 58,3 & 20 & 83,3 \\
Kurang Baik & 10 & 41,7 & 4 & 16,7 \\
\hline Jumlah & 24 & 100 & 24 & 100 \\
\hline
\end{tabular}

Dari tabel .1 diketahui bahwa pengetahuan baik sebelum diberikan konseling dengan media lembar balik (pre-test) sebanyak 58,3\% dan setelah diberikan konseling dengan media lembar balik (post-test) sebanyak 83,3\% sedangkan pengetahuan kurang baik sebelum diberikan konseling dengan media lembar balik (pre-test) sebanyak 41,7\% dan setelah diberikan konseling dengan media lembar balik (post-test) sebanyak 16,7\%.

Tabel .2 Hasil Distribusi Frekuensi Pengetahuan Tentang Gaya Hidup Pada Pasien Di Poliklinik Rawat Jalan RSUD Deli Serdang Tahun 2019 Pada Kelompok Media Brosur

\begin{tabular}{lllll}
\hline \multirow{2}{*}{ Variabel Pengetahuan } & \multicolumn{3}{l}{ Media Brosur } & \multicolumn{2}{l}{ Post Test } \\
\cline { 2 - 5 } & \multicolumn{2}{l}{ Pre-Test } & f & \% \\
\cline { 2 - 5 } & $\mathbf{f}$ & \% & f & 91,7 \\
Baik & 15 & 62,5 & 22 & 8,3 \\
Kurang Baik & 9 & 37,5 & 2 & 100 \\
\hline Jumlah & 24 & 100 & 24 & \\
\hline
\end{tabular}

Dari tabel .2 diketahui bahwa pengetahuan baik sebelum diberikan konseling dengan media brosur (pre-test) sebanyak 62,5\% dan setelah diberikan konseling dengan media brosur (posttest) sebanyak $91,7 \%$ sedangkan pengetahuan kurang baik sebelum diberikan konseling dengan media brosur (pre-test) sebanyak 37,5\% dan setelah diberikan konseling dengan media brosur (post-test) sebanyak 8,3\%. 


\section{Hasil Analisa Bivariat}

Tabel .3 Hasil Pre-Test dan Post-Test Pengetahuan Tentang Gaya Hidup Pada Kelompok Media Lembar Balik Pada Pasien Penderita DM Tipe 2 Di Poliklinik Rawat Jalan RSUD Deli Serdang Tahun 2019

\begin{tabular}{llll}
\hline $\begin{array}{l}\text { Variabel Pengetahuan } \\
\text { Kelompok Media Lembar } \\
\text { Balik }\end{array}$ & Mean & SD & $\begin{array}{l}\text { Sig. } \\
\text { tailed) }\end{array}$
\end{tabular}

Dari tabel .3 di atas dari hasil uji statistik diketahui bahwa pengetahuan responden sebelum diberikan konseling dengan media lembar balik (pre-test) dengan nilai rata-rata (mean) sebesar 5,67 dan setelah diberikan konseling dengan media lembar balik (post-test) diperoleh nilai ratarata (mean) sebesar 7,04 yang menunjukkan adanya peningkatan setelah diberi konseling dengan media lembar balik.

Tabel .4 Hasil Pre-Test dan Post-Test Pengetahuan Tentang Gaya Hidup Pada Kelompok Media Brosur Pada Pasien Penderita DM Tipe 2 Di Poliklinik Rawat Jalan RSUD Deli Serdang Tahun 2019

\begin{tabular}{|c|c|c|c|}
\hline $\begin{array}{l}\text { Variabel Pengetahuan } \\
\text { Kelompok Media Brosur } \\
\end{array}$ & Mean & SD & $\begin{array}{l}\text { Sig. } \\
\text { tailed })\end{array}$ \\
\hline Pre-Test & 6,29 & & \\
\hline Post-Test & 8,46 & ניכ, & 0,000 \\
\hline
\end{tabular}

Dari tabel 4 di atas dari hasil uji statistik diketahui bahwa pengetahuan responden sebelum diberikan konseling dengan media brosur (pre-test) dengan nilai rata-rata (mean) sebesar 6,29 dan setelah diberikan konseling dengan media brosur (post-test) diperoleh nilai rata-rata (mean) sebesar 8,46 yang menunjukkan adanya peningkatan setelah diberi konseling dengan media brosur.

Tabel .5 Efektifitas Antara Media Lembar Balik DenganMedia Brosur Terhadap Pengetahuan Tentang Gaya Hidup Di Poliklinik Rawat Jalan RSUD Deli Serdang Tahun 2019

\begin{tabular}{llll}
\hline \multirow{2}{*}{ Variabel } & \multicolumn{2}{l}{ Mean Rank } & \multirow{2}{*}{ Sig. } \\
\cline { 2 - 3 } & $\begin{array}{l}\text { Media Lembar } \\
\text { Balik }\end{array}$ & Media Brosur & \\
\hline Pengetahuan & 18,50 & 30,50 & 0,002 \\
\hline
\end{tabular}

Berdasarkan tabel .5 di atas diketahui bahwa variabel pengetahuan dengan media lembar balik diperoleh nilai mean rank $=18,5$ sedangkan dengan media brosur diperoleh nilai mean rank $=$ 30,5 dan signifikan $=0,002$ yang menunjukkan bahwa media brosur lebih efektif dibandingkan dengan media lembar balik. 
Berdasarkan hasil uji statistik antara konseling dengan media lembar balik terhadap pengetahuan tentang gaya hidup diperoleh nilai $\mathrm{p}=0,000<0,05$ yang memiliki arti bahwa ada pengaruh konseling dengan media lembar balik terhadap pengetahuan tentang gaya hidup pada pasien penderita DM tipe 2 di Poliklinik Rawat Jalan RSUD Deli Serdang tahun 2019.

Pengaruh konseling menggunakan media lembar balik terhadap pengetahuan tentang gaya hidup pada pasien penderita DM tipe 2 dapat dilihat dari pendapat Munadi (2012) yang menyatakan bahwa media lembar balik adalah lembaran-lembaran kertas dimana terdapat gambar yang besar yang dibalikkan pada sebuahgantungan. Dari pendapat tersebut dapat diketahui bahwa lembar balik dapatdigunakansebagai media penyampaian pesan pembelajaran atau informasi tentang gaya hidup.Penggunaan media lembar balik merupakan cara dalam menghemat waktuuntuk menulis dan menjelaskan. Lembar balik merupakan mediacetakan yang sangat sederhana dan cukup efektif. Dikatakan efektif karena lembarbalikdapat dijadikan sebagai media (pengantar) pesan pembelajaran atau informasiyang secara terencana ataupun secara langsung disajikan pada lembar balik tersebut.

Hal ini dapat dilihat dari penderita DM tipe 2 dimana sebelum diberikan konseling tentang gaya hidup menggunakan media lembar balik diperoleh nilai rata-rata 5,67, namun setelah diberikan konseling menggunakan media lembar balik ternyata adanya peningkatan pengetahuan dengan rata-rata menjadi 7,04. Peningkatan pengetahuan yang paling menonjol tersebut adalah tentang suatu kumpulan keluhan sakit yang disebabkan oleh kadar gula tinggi dan kurangnya insulin adalah diabetes mellitus serta semua orang bisa terkena penyakit diabetes mellitus. Oleh karena itu konseling merupakan suatu kegiatan dalam rangka memberikan pelayanan kepada penderita DM tipe 2 yang membutuhkan informasi, bantuan atau penyuluhan yang berkaitan dengan keadaan diri penderita tersebut khususnya gaya hidup yang harus dijalani pada penderita DM tipe 2.Setiawan (2018) menyebutkan bahwa konseling sebagai suatu ilmu yang memiliki pengertian yang sangat mendalam sesuai dengan konsep yang dikembangkan dalam profesinya. Konseling tercipta karena adanya interaksi antara dua orang individu, yaitu konselor (pemberi bantuan/informasi) dan konseli (penerima bantuan/informasi). Division of Counseling Psychologymengartikan konseling sebagai suatu proses untuk membantu individu mengatasi hambatan-hambatan perkembangan dirinya dan untuk mencapai perkembangan yang optimal kemampuan pribadi yang dimilikinya, proses tersebut dapat terjadi setiap waktu.

Menurut Munadi (2012), media papan lembar balik (flip chart) yaitu media pembelajaran yangberbentuk lembaran-lembaran kertasberisi pesan atau bahan pelajaran yangdigantungkan pada sebuah gantungan sehingga mudah untuk dibalik. Lembarkertas ini berisikan bahan pelajaran berupa gambar maupun tulisan dengandesain dan variasi warna sesuai dengan kreativitas agar terlihat menarik. Dari pendapat tersebut diketahui bahwa penderita DM menerima informasi berkaitan dengan penyakit yang dideritanya pada saat konseling itu terjadi. Namun ketika kegiatan konseling tersebut selesai, ada kemungkinan penderita DM lupa dari apa yang telah disampaikan sehingga mempengaruhi tingkat penyerapan pengetahuan dari penderita DM tersebut.

Pentingnya konseling bagi penderita DM dapat diketahui melalui penelitian Rahmat (2010) dimana hasilnya penelitiannya menunjukkan bahwa terdapat pengaruh konseling terhadappeningkatan pengetahuan pasien Diabetes Mellitus tipe 2 di Puskesmas Kopelma Darussalam Banda Aceh, lebih spesifik didapatkan onseling pada pengetahuan pola makan berpeluang 5,59\% untuk berhasil meningkatkan pengetahuan. Hasil penelitian Rahmat tersebut juga sejalan dengan penelitian Thomas, et al.

(2017) yang berjudul "Impact of patient 
counselling on knowledge, attitude, and practice of hypertensive patients in a tertiary care hospital'menyatakan bahwa terdapat peningkatan yang signifikan terhadap pengetahuan, sikap dan tindakan setelah pasien mendapatkan konseling.

Berdasarkan hasil uji statistik antara konseling dengan media brosur terhadap pengetahuan tentang gaya hidup diperoleh nilai $\mathrm{p}=0,000<0,05$ yang memiliki arti bahwa ada pengaruh konseling dengan media brosur terhadap pengetahuan tentang gaya hidup pada pasien penderita DM tipe 2 di Poliklinik Rawat Jalan RSUD Deli Serdang tahun 2019.

Notoatmodjo (2012) mengartikan brosur adalah suatu alat untuk promosi barang, jasa dan lainlain, yang terbuat dari kertas yang dimana didalamnya terdapat sejumlah informasi dan juga penawaran mengenai jasa atau produk tersebut. Sementara menurut Prastowo (2012), brosur merupakan bahan informasi tertulis mengenai suatu masalah yangdisusun secara sistematis. Brosur dapat juga diartikan sebagai selebaran cetakan yang berisi keterangan singkat dan lengkap.

Menurut Riyana (2012), brosur yang dibuat dengan bahan cetak yang tebal, mungkin akan membuat bosanpembacanya. Dari pendapat tersebut dapat diketahui bahwa penderita DM dapat terpengaruh pada brosur yang berisikan banyak informasi sehingga menimbulkan kemalasan bagi penderita DM untuk membacanya yang pada akhirnya berdampak pada tingkat pengetahuannya. Hal ini terlihat dari data diketahui dari hasil pertanyaan yang diberikan pada saat pre-test, tidak menunjukkan peningkatan pada saat post test dilakukan sehingga berdasarkan hal tersebut, maka brosur yang dibuat harus mempertimbangkan materi yang dicantumkan di dalam brosur tersebut agar penderita DM yang membacanya tidak menimbulkan kebosanan.

Selanjutnya berdasarkan hasil uji statistik diketahui bahwa konseling dengan media brosur lebih efektif berpengaruh terhadap pengetahuan tentang gaya hidup pada pasien penderita DM tipe 2 di di Poliklinik Rawat Jalan RSUD Deli Serdang. Hal ini disebabkan media brosur yang berbentuk selebaran cetakan dapat dibawa kemana saja oleh penderita DM tipe 2 tersebut serta dapat diletakkan di dalam rumah sebagai pengingat untuk melakukan gaya hidup yang sehat. Sedangkan pada media lembar balik hanya dapat digunakan pada saat melakukan penyuluhan atau pembelajaran berlangsung saja sehingga penderita DM tipe 2 bisa tidak mengingat apa yang sudah diberikan melalui penyuluhan menggunakan media lembar balik.

\section{KESIMPULAN DAN SARAN}

Secara keseluruhan dapat disimpulkan bahwa pengaruh konseling dengan media brosur lebih efektif dibandingkan konseling dengan media lembar balik terhadap pengetahuan tentang gaya hidup pada pasien penderita DM tipe 2 di Poliklinik Rawat Jalan RSUD Deli Serdang. Adapun saran bagi Pihak Rumah Sakit Untuk meningkatkan pemahaman tentang gaya hidup yang sehat bagi penderita DM tipe 2, pihak rumah sakit dapat membuat konseling melalui media brosur karena efektif untuk meningkatkan pengetahuan pasien. Selain itu diharapkan juga bagi pihak rumah sakit untuk selalu memberikan penyuluhan tentang diabetes dan gaya hidup yang sehat pada waktu-waktu tertentu bagi penderita dan juga masyarakat di rumah sakit sebagai wujud kepedulian rumah sakit kepada penderita diabetes dan masyarakat untuk menciptakan masyarakat yang sehat dengan bebas dari penyakit diabetes. 


\section{Ucapan Terima Kasih}

Penulis mengucapkan terima kasih kepada direktur RSUD Deli Serdang yang telah memberikan izin dan dukungan untuk penelitian ini.

\section{REFERENSI}

Depkes RI. (2000). Perawatan Penyakit Dalam Dan Bedah. Jakarta.

Depkes RI. (2010). Undang-Undang Nomor: 340 Tahun 2010 Tentang Klasifikasi Rumah Sakit. Jakarta

Kementrian Kesehatan RI. (2014). Pedoman Gizi Seimbang. Jakarta: Direktorat Jenderal Bina Gizi dan KIA.

Munadi, Yudhi. (2012). Media Pembelajaran, sebuah pendekatan baru. Jakarta: Gaung Persada Press

Notoatmodjo. (2012). Promosi Kesehatan Dan Perilaku Kesehatan. Jakarta: Rineka Cipta.

Rachmawati, Meilisa; Risqa Rina Darwita\& Febriana Setiawati, 2012. Peran Media Lembar Balik Dalam Meningkatkan Perilaku Ibu Terhadap Kesehatan Gigi dan Mulut Anak Dan Evaluasi Dengan KMGS (Studi Klinis di Posyandu Soka Tahun 2012).

Setiawan. (2018). Pendekatan-Pendekatan Konseling (Teori dan Aplikasi). Yogyakarta: Deepublish

Tuncay, T., et al. (2008). The Relationship Between axiety, Coping Strategies and Characteristic of Patients with Diabetes. Health and Quality of Life Outcomes, 6:79

Undang-Undang Republik Indonesia No. 36 Tahun 2009 Tentang Kesehatan

WHO. ( 2016). Global Report On Diabetes. France: World Health Organization

WHO. (2015). World Health Statistics 2015.France: World Health Organization. 